\title{
Cutting Conditions and Tool Wear when Machining Wood-Based Materials
}

Josef Chladil, ${ }^{\mathrm{a} *}$ Josef Sedlák, ${ }^{\mathrm{a}}$ Eva Rybářová Šebelová, ${ }^{\mathrm{b}}$ Marián Kučera, ${ }^{\mathrm{c}}$ and Miroslav Dado ${ }^{c}$

The article deals with data in the cutting process of wood-based materials. The cutting process influences the shape and dimensions of a cutting edge. The experiments were focused on monitoring the changes of the cutting edge in machining of particle board and the influence of cutting speed on the tool wear. Cutting tests were performed during milling at cutting rates in the range 7.95 to $17.9 \mathrm{~m} / \mathrm{s}(477$ to $1074 \mathrm{~m} / \mathrm{min})$, a depth of cut of $9.5 \mathrm{~mm}$, and a tooth feed of $0.05 \mathrm{~mm}$. The wear process of cutting wedge during particle board milling is characterized by a decrease in the cutting edge of insert blades. The comparative digital dial gauge was used for measurement of the cutting wedge recession. The course of the wear of wood based materials exhibited similarity in graphical representation with abrasive material cutting. The resulting dependency may be used for selection of the most suitable cutting conditions according to operator requirements.

Keywords: Machining; Wood; Tool; Wear; Dulling; Cutting conditions

Contact information: a: Institute of Manufacturing Engineering, Faculty of Mechanical Engineering and Technology, Brno University of Technology, Technická 2, 61600 Brno, Czech Republic, b: The Display Company CZ s.r.o., Londýnské námèstí 4, 63900 Brno, Czech Republic, c: Department of Manufacturing Technology and Quality Management, Faculty of Environmental and Manufacturing Technology, Technical University in Zvolen; * Corresponding author: jo.chla@ seznam.cz

\section{INTRODUCTON}

Wood is a porous and fibrous structural tissue found in the stems and roots of trees and other woody plants. It is an organic material, a natural composite of cellulose fibers, which are strong in tension and embedded in a matrix of lignin that resists compression. Wood is the one of few materials that are renewable (Kučerová et al. 2016). Unfortunately, wood is a relatively low-durability material and requires special care to assure a long-term service life. For that reason, modified or surface-coated wood-based materials are also widely used. To a certain extent, such wood-based materials preserve the good properties of wood and mitigate against some of its unfavorable properties (Kvietkova et al. 2015a,b,c; Gaff et al. 2016; Sedlecký and Sarvašová Kvietková 2017).

Mechanical and physical properties are important factors in wood processing. Agglomerated materials are made from wood or other lignocellulosic particles.

Particle board is a term for material made of wood particles that are produced in variety of shapes and sizes. Wood chips are bonded using synthetic glue, high pressure, and increased temperature. For interior use, these materials often need to be veneered, laminated, or folded to improve their appearance. The material is most widely used and most manufactured agglomerated material in the woodworking industry (Thoemen et al. 2010).

During the milling process, cutting inserts within the rotating tool separate the 
workpiece material in the form of chips. The feed rate is limited by size and type of cutting tool perpendicular to the machined part. The cutting process is intermittent, and the cutter teeth alternately cut short chips of varying thickness. Wood-based materials are milled in all directions, but most often along the direction of wood fibres. The direction of rotation is usually chosen to be conventional, i.e. against the feed rate direction. With respect to the position of the axis of rotation and the surfaces created by the cutting edges, the milling is divided into two types: either the cylindrical-tool axis is parallel with the workpiece surface, or the front-axis of the tool is perpendicular to the workpiece surface.

The milling process is monitored using the tool life. Tool life is the period during which the blade is in working condition in the machining process. It is the time when the tool is working, from sharpening to dulling. When machining the metal, abrasion wear process is observed on the clearance face of cutting edge and is referred to as VB flank wear. Figure 1 shows this process on the wear curve. The individual phases are: I - initial rapid wear, II - linear wear, and III - final unstable course. The practical wear measurement uses the value of critical wear VB in the linear phase II; this selection is due to the accuracy of the reading value (Shaw 2005; Csanády and Magoss 2012).

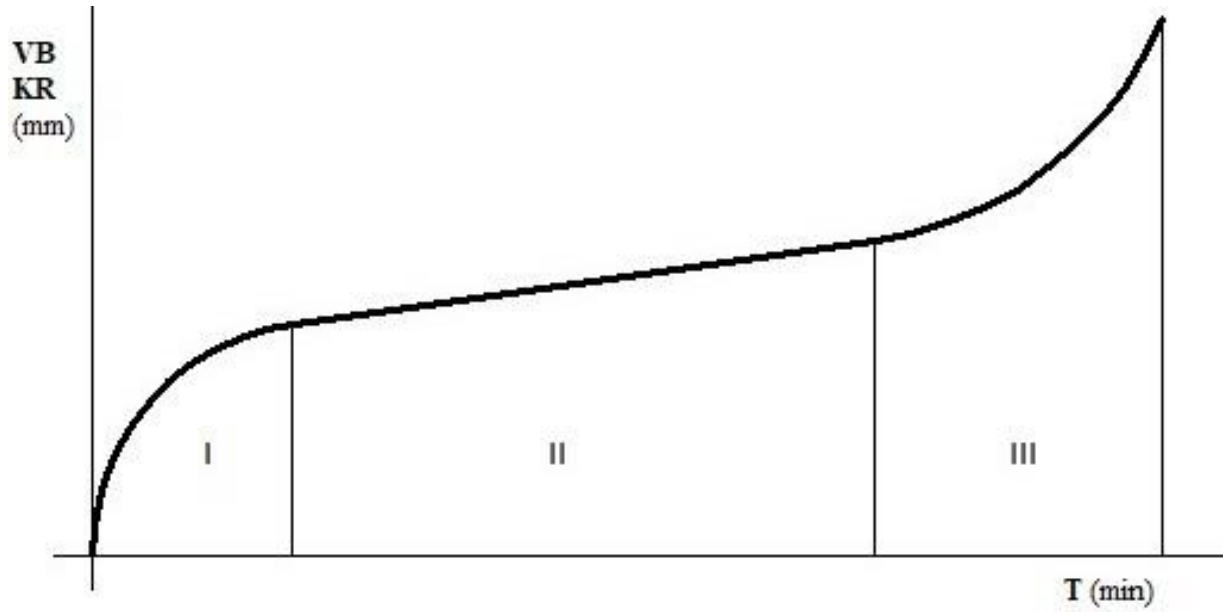

Fig. 1. Graphical representation of the dependence VB or $K R=f n(T)$ in metal cutting

The cutting edge is formed by the intersection of two surfaces - the face plane (rake angle $\gamma$ ) and the clearance plane (clearance angle $\alpha$ ). Darmawan et al. $(2001,2012)$ studied wear process on the clearance face influenced by different wood based materials and materials of cutting tool edge. During machining wood based materials without abrasives the wear on the tool edge recession is monitored depending on time (Šebelová and Chladil 2013). This type of wear is called nose wear (Shaw 2005; Mazan et al. 2017), and its size corresponds to radial wear KR (see Fig. 2).

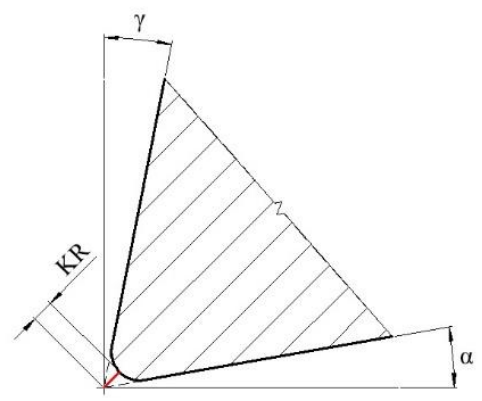

Fig. 2. The nose wear type of tool wear 
In this study, a wood-based material - laminated particle board - was used to experimentally examine the influence of cutting conditions on tool wear. Cylindrical milling was used to test properties of the tool material in the cutting process, and a twotooth right-hand milling cutter was applied. The tool dulling process was monitored because this affects cutting tool lifetime and thus also the machining efficiency. The Taylor's time vs. cutting speed formula was used for evaluation (Shaw 2005).

\section{EXPERIMENTAL}

\section{Workpiece Material}

Laminated particle board was used as the representative of wood-based materials laminated with beech. The supplier of the laminated particle board (045 BS beech Westfalen 18mm thick) was INTEREXPO Brno Ltd, Czech Republic. The board volume weight was 600 to $750 \mathrm{~kg} \cdot \mathrm{m}^{-3}$ and moisture $14.2 \%$ determined according to EN 323 (1993).

\section{Cutting Tool}

The two-teeth clockwise milling cutter FRSTHW 19x30x12z2 (Aparathea Ltd., Brno, Czech Republic) with diameter D of $19 \mathrm{~mm}$ was used for experiments. Cutter inserts

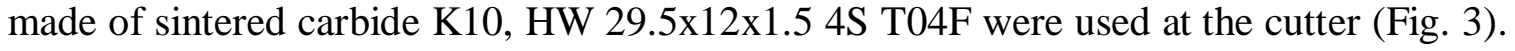
The cutting tool geometry: rake angle $\gamma$ of $15^{\circ}$ and clearance angle $\alpha$ of $20^{\circ}$.

\section{Fig. 3. Milling cutter HW $19 \times 30$}

Sintered carbide (SC) inserts were clamped into the milling cutter and secured with a bolt. The carbide inserts were identified by a letter with the appropriate symbol-letter to distinguish use in the machining of individual samples and for the uniqueness of the individual measurements. The number denoted a particular cutting inserts had the lower letter case a / b to distinguish the blade side. Cutting inserts marked U1 to U4 Fig. 4 were used for cutting the laminated particle board.
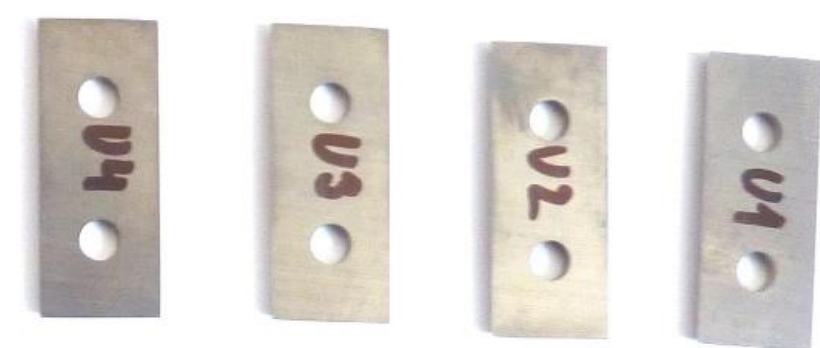

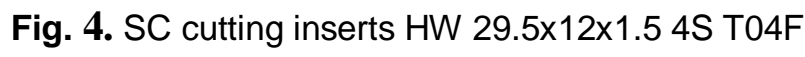




\section{Machine Tool}

The selected materials were machined on a three axis milling CNC machine SCM Tech 99 (Rimini, Italy) with the following parameters: working dimensions X, $3119 \mathrm{~mm}$, $\mathrm{Y}, 1012 \mathrm{~mm}, \mathrm{Z}, 100 \mathrm{~mm}$; motor power, $6.6 \mathrm{~kW}$, and maximum rotational speed of 1800 $\mathrm{rpm}$. The two-teeth clockwise milling cutter was clamped in the milling CNC machine.

\section{Methods}

\section{Cutting conditions}

A climb milling was selected for machining. The range of minimum $4000 \mathrm{rpm}$ and a maximum $18000 \mathrm{rpm}$ were determined for a constant feed on the tooth $\left(f_{\mathrm{z}}=0.05 \mathrm{~mm}\right)$ and a constant width of cut $a_{\mathrm{p}}=18 \mathrm{~mm}$ (material thickness). Cutting and feed rate values are based on the relationship between tooth feed value, cutting speed, tool speed, and cutter diameter. All variables are defined in Table 1. The cutting speed $\left(v_{c}\right)$ was determined by Eqs. 1 and 2.

$$
\begin{aligned}
& v_{c}=\frac{\pi \cdot D \cdot n}{10^{3}} \quad\left[\mathrm{~m} \cdot \mathrm{min}^{-1}\right] \\
& n=\frac{10^{3} \cdot v_{c}}{\pi \cdot D} \quad[\mathrm{rpm}]
\end{aligned}
$$

The feed rate $\mathrm{v}_{\mathrm{f}}$ was calculated by Eq. 3 .

$$
v_{f}=f_{z} \cdot z \cdot n \quad\left[\mathrm{~mm} \cdot \mathrm{min}^{-1}\right]
$$

Table 1. Process Conditions of Cutting for Experiments

\begin{tabular}{|l|l|}
\hline Parameter & Value \\
\hline Tool diameter $D(\mathrm{~mm})$ & 19 \\
\hline Feed per tooth $f_{z}(\mathrm{~mm})$ & 0.05 \\
\hline Number of teeth $z$ & 2 \\
\hline Depth of cut $h_{\max }(\mathrm{mm})$ & 9.5 \\
\hline Speed range $n$ used $(\mathrm{rpm})$ & $8000,12000,15000,18000$ \\
\hline Feed rates $V_{f}\left(\mathrm{~mm} \cdot \mathrm{min}^{-1}\right)$ & $800,1200,1500,1800$ \\
\hline Corresponding cutting speeds $v_{c}\left(\mathrm{~m} \cdot \mathrm{min}^{-1}\right)$ & $477,716,895,1074$ \\
\hline Basic length of cut $L(\mathrm{~mm})$ & 700 \\
\hline
\end{tabular}

\section{Tool wear}

The tool life of the cutting edge is most affected by the cutting speed $v_{\mathrm{c}}$. Experimental determination of the tool life dependence on the cutting speed, i.e., $T=\mathrm{fn}\left(v_{\mathrm{c}}\right)$, was carried out using several cutting speeds. It was necessary to ensure that other working conditions were constant. The wear on the tool was represented by the wear curves for individual cutting speeds in the diagram $\mathrm{KR}=\mathrm{fn}(T)$ for radial wear. Measurement of flank wear VB mainly used in metal cutting could not be used due to the difficulty measuring any changes during the experiments.

To measure the radial wear of the KR tool, which is defined by the dependence KR $=\mathrm{fn}(T)$, it was necessary to calculate the time according to the following equation,

$$
T=\frac{L}{v_{f}} \quad\left[\mathrm{~mm} \cdot \mathrm{min}^{-1}\right]
$$


where $T$ is the cutting time ( $\mathrm{min}), L=700$ is the length of workpiece (mm), and $v_{\mathrm{f}}$ is the feed rate $\left(\mathrm{mm} \cdot \mathrm{min}^{-1}\right)$. The tool wear criterion was determined as $\mathrm{KR}=10 \mu \mathrm{m}$.

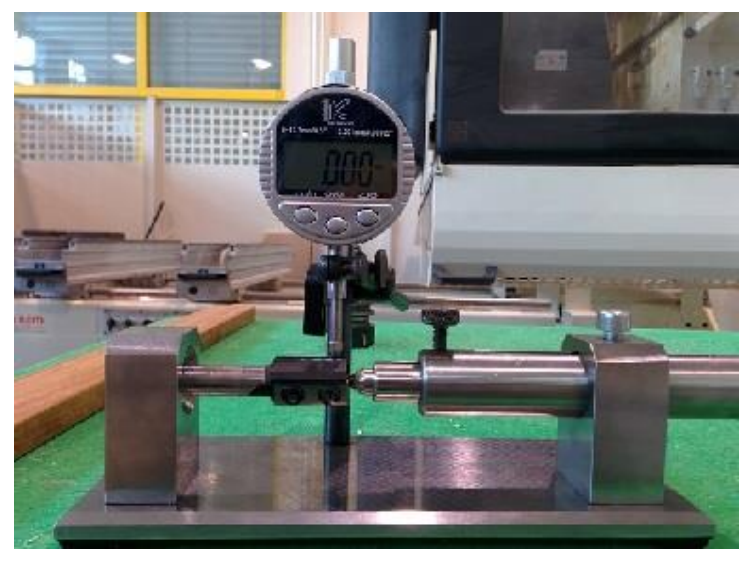

Fig. 5. The comparison measurement instrument

\section{Measuring equipment}

To measure the tool wear, a digital dial gauge (KINEX 0-12.7 / 0.001, Prague, Czech Republic) was fixed on a measurement jig that was developed for the experiments see Fig. 5. The instrument measures deviations from the set dimension. First, it was necessary to calibrate the instrument according to the new tool inserts. The device used had measurement accuracy of $1 \mu \mathrm{m}$ and maximum touch stroke of $12.7 \mathrm{~mm}$.

\section{Evaluation of measured values}

Minitab® 15 statistical software (State College, PA, USA) was used to evaluate the measured values from experiments.

\section{RESULTS AND DISCUSSION}

\section{Radial Wear vs. Time}

The radial wear KR of the cutting tool is time dependent.

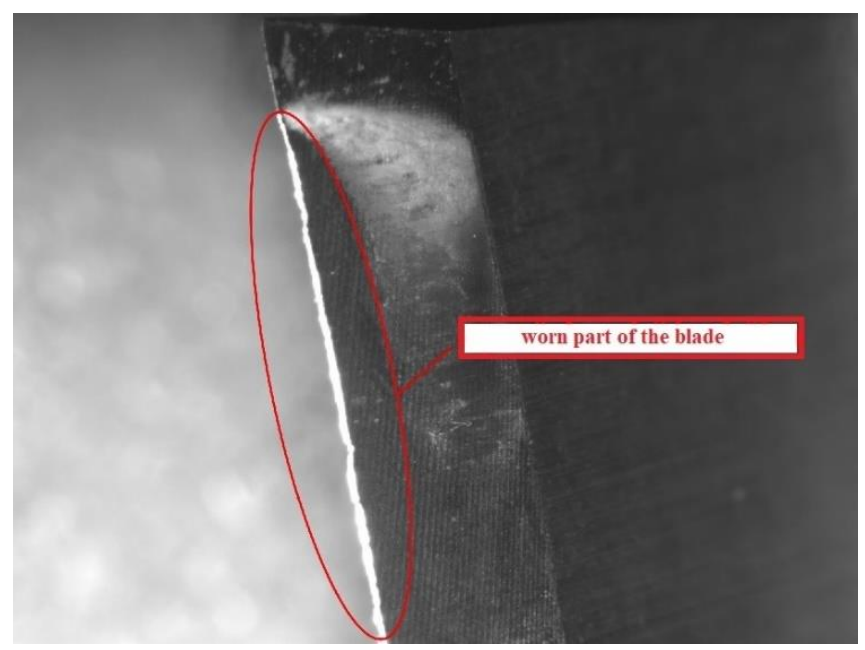

Fig. 6. Tool wear of a cutting insert (red colored mark) 
At time intervals that are given by the time of cutting, KR wear measurement has been performed. The results are further elaborated in time dependence graphs. The tool wear of inserts is shown using red colored mark in Fig. 6.

The resulting dependencies of the tool wear $\mathrm{KR}=\mathrm{fn}(T)$, taken from the linear part wear that are highlighted in gray in tables, are attached to the tables of measurement in Figs. 7 to 10 .

Table 2. Measurement of Tool Wear vs. Time, Inserts U1a / U2a, Speed $v_{\mathrm{c} 1}=477$ $\mathrm{m} / \mathrm{min}$

\begin{tabular}{|c|c|c|c|c|c|}
\hline $\begin{array}{c}\text { Measurement } \\
\text { No. }\end{array}$ & $\begin{array}{c}\text { Time } \\
(\mathrm{min})\end{array}$ & $\begin{array}{c}\text { Length of cut } \\
(\mathrm{mm})\end{array}$ & $\begin{array}{c}\text { Wear of U1a } \\
(\mu \mathrm{m})\end{array}$ & $\begin{array}{c}\text { Wear of U2a } \\
(\mu \mathrm{m})\end{array}$ & $\begin{array}{c}\text { Average } \\
\text { wear }(\mu \mathrm{m})\end{array}$ \\
\hline 1 & $\mathbf{0}$ & 0 & 0 & 0 & $\mathbf{0}$ \\
\hline 2 & $\mathbf{1 . 7 5}$ & 1400 & 2 & 1 & $\mathbf{1 . 5}$ \\
\hline 3 & $\mathbf{3 . 5 0}$ & 1400 & 3 & 3 & $\mathbf{3 . 0}$ \\
\hline 4 & $\mathbf{5 . 2 5}$ & 1400 & 4 & 4 & $\mathbf{4 . 0}$ \\
\hline 5 & $\mathbf{1 0 . 5 0}$ & 4200 & 5 & 5 & $\mathbf{5 . 0}$ \\
\hline 6 & $\mathbf{1 9 . 2 5}$ & 7000 & 6 & 6 & $\mathbf{6 . 0}$ \\
\hline 7 & $\mathbf{3 6 . 7 5}$ & 14000 & 8 & 7 & $\mathbf{7 . 5}$ \\
\hline 8 & $\mathbf{5 4 . 2 5}$ & 14000 & 9 & 9 & $\mathbf{9 . 0}$ \\
\hline 9 & $\mathbf{7 1 . 7 5}$ & 14000 & 11 & 11 & $\mathbf{1 1 . 0}$ \\
\hline 10 & $\mathbf{8 9 . 2 5}$ & 14000 & 13 & 12 & $\mathbf{1 2 . 5}$ \\
\hline 11 & $\mathbf{1 0 6 . 7 5}$ & 14000 & 15 & 14 & $\mathbf{1 4 . 5}$ \\
\hline
\end{tabular}

Table 3. Measurement of Tool Wear vs. Time, Inserts U1b / U2b, Speed $v_{c 2}=716$ $\mathrm{m} / \mathrm{min}$.

\begin{tabular}{|c|c|c|c|c|c|}
\hline $\begin{array}{c}\text { Measurement } \\
\text { No. }\end{array}$ & $\begin{array}{c}\text { Time } \\
(\mathrm{min})\end{array}$ & $\begin{array}{c}\text { Length of cut } \\
(\mathrm{mm})\end{array}$ & $\begin{array}{c}\text { Wear of U1b } \\
(\mu \mathrm{m})\end{array}$ & $\begin{array}{c}\text { Wear of U2b } \\
(\mu \mathrm{m})\end{array}$ & $\begin{array}{c}\text { Average } \\
\text { wear }(\mu \mathrm{m})\end{array}$ \\
\hline 1 & $\mathbf{0}$ & 0 & 0 & 0 & $\mathbf{0}$ \\
\hline 2 & $\mathbf{1 . 1 7}$ & 1400 & 2 & 1 & $\mathbf{1 . 5}$ \\
\hline 3 & $\mathbf{2 . 3 4}$ & 1400 & 3 & 3 & $\mathbf{3 . 0}$ \\
\hline 4 & $\mathbf{5 . 8 4}$ & 4200 & 5 & 4 & $\mathbf{4 . 5}$ \\
\hline 5 & $\mathbf{9 . 3 4}$ & 4200 & 7 & 6 & $\mathbf{6 . 5}$ \\
\hline 6 & $\mathbf{1 5 . 1 7}$ & 7000 & 9 & 8 & $\mathbf{8 . 5}$ \\
\hline 7 & $\mathbf{2 1 . 0 0}$ & 7000 & 10 & 9 & $\mathbf{9 . 5}$ \\
\hline 8 & $\mathbf{3 2 . 6 7}$ & 14000 & 11 & 10 & $\mathbf{1 0 . 5}$ \\
\hline 9 & $\mathbf{4 4 . 3 4}$ & 14000 & 11 & 11 & $\mathbf{1 1 . 0}$ \\
\hline 10 & $\mathbf{5 6 . 0 1}$ & 14000 & 12 & 11 & $\mathbf{1 1 . 5}$ \\
\hline 11 & $\mathbf{6 7 . 6 8}$ & 14000 & 13 & 13 & $\mathbf{1 3 . 0}$ \\
\hline 12 & $\mathbf{7 9 . 3 5}$ & 14000 & 15 & 14 & $\mathbf{1 4 . 5}$ \\
\hline
\end{tabular}




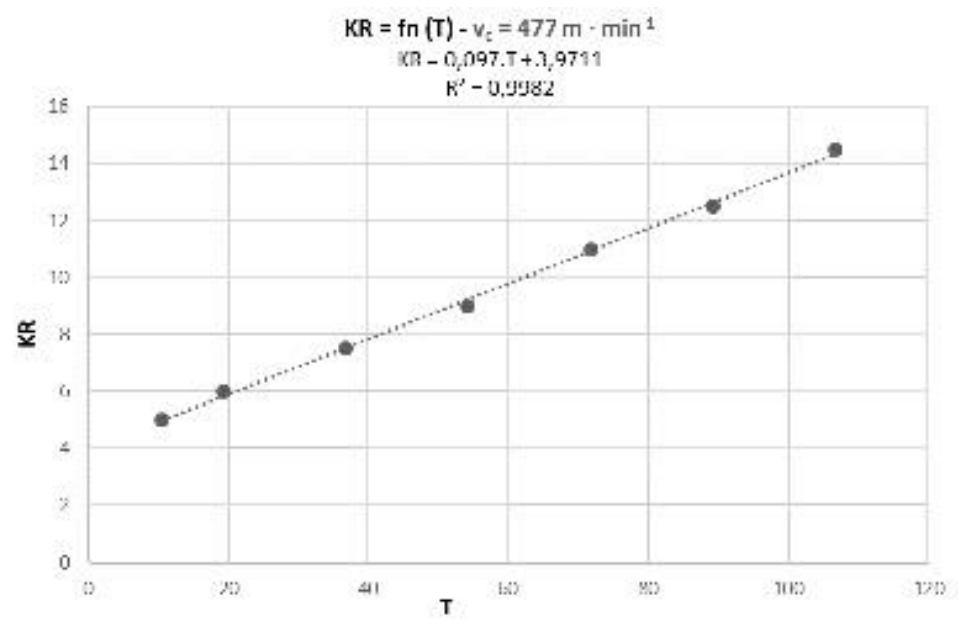

Fig. 7. The regression of linear wear for $v_{\mathrm{c} 1}=477 \mathrm{~m} / \mathrm{min}, \mathrm{KR}[\mu \mathrm{m}]$ and $T[\mathrm{~min}]$

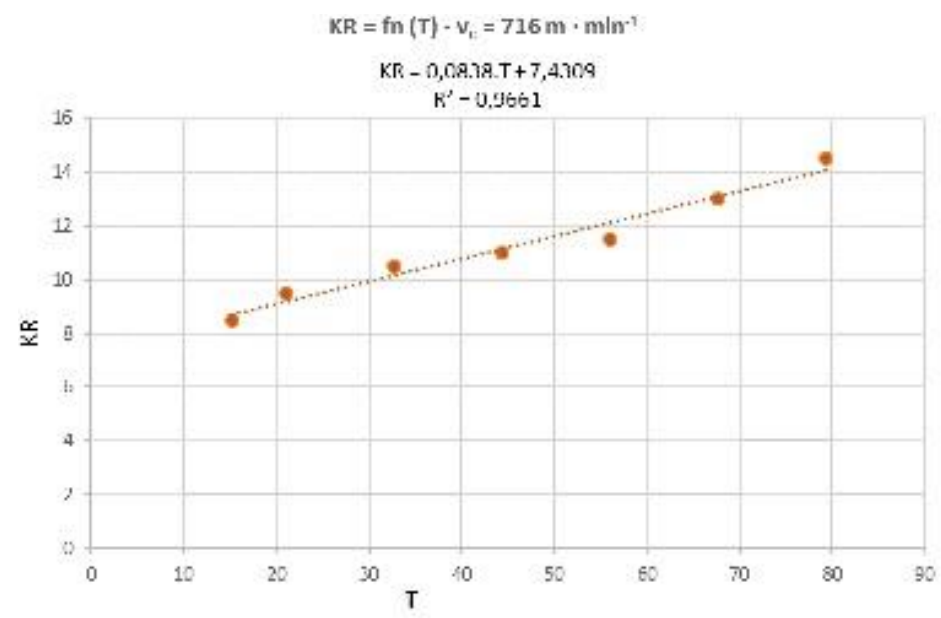

Fig. 8. The regression of linear wear for $v_{\mathrm{c} 2}=716 \mathrm{~m} / \mathrm{min}, \mathrm{KR}[\mu \mathrm{m}]$ and $T[\mathrm{~min}]$

Table 4. Measurement of Tool Wear vs. Time, Inserts U3a / U4a, Speed $v_{\mathrm{c} 3}=895$ $\mathrm{m} / \mathrm{min}$

\begin{tabular}{|c|c|c|c|c|c|}
\hline $\begin{array}{c}\text { Measurement } \\
\text { No. }\end{array}$ & $\begin{array}{c}\text { Time } \\
(\mathrm{min})\end{array}$ & $\begin{array}{c}\text { Length of cut } \\
(\mathrm{mm})\end{array}$ & $\begin{array}{c}\text { Wear of U3a } \\
(\mu \mathrm{m})\end{array}$ & $\begin{array}{c}\text { Wear of U4a } \\
(\mu \mathrm{m})\end{array}$ & $\begin{array}{c}\text { Average } \\
\text { wear }(\mu \mathrm{m})\end{array}$ \\
\hline 1 & $\mathbf{0}$ & 0 & 0 & 0 & $\mathbf{0}$ \\
\hline 2 & $\mathbf{0 . 7 8}$ & 700 & 2 & 2 & $\mathbf{2 . 0}$ \\
\hline 3 & $\mathbf{1 . 5 6}$ & 700 & 3 & 3 & $\mathbf{3 . 0}$ \\
\hline 4 & $\mathbf{2 . 3 5}$ & 700 & 4 & 4 & $\mathbf{4 . 0}$ \\
\hline 5 & $\mathbf{3 . 9 1}$ & 1400 & 6 & 5 & $\mathbf{5 . 5}$ \\
\hline 6 & $\mathbf{5 . 4 8}$ & 1400 & 7 & 6 & $\mathbf{6 . 5}$ \\
\hline 7 & $\mathbf{1 0 . 1 7}$ & 4200 & 9 & 8 & $\mathbf{8 . 5}$ \\
\hline 8 & $\mathbf{1 4 . 8 6}$ & 4200 & 9 & 9 & $\mathbf{9 . 0}$ \\
\hline 9 & $\mathbf{2 2 . 6 8}$ & 7000 & 11 & 10 & $\mathbf{1 0 . 5}$ \\
\hline 10 & $\mathbf{3 8 . 3 2}$ & 14000 & 12 & 12 & $\mathbf{1 2 . 0}$ \\
\hline 11 & $\mathbf{5 3 . 9 7}$ & 14000 & 14 & 14 & $\mathbf{1 4 . 0}$ \\
\hline 12 & $\mathbf{6 9 . 6 1}$ & 14000 & 16 & 16 & $\mathbf{1 6 . 0}$ \\
\hline
\end{tabular}




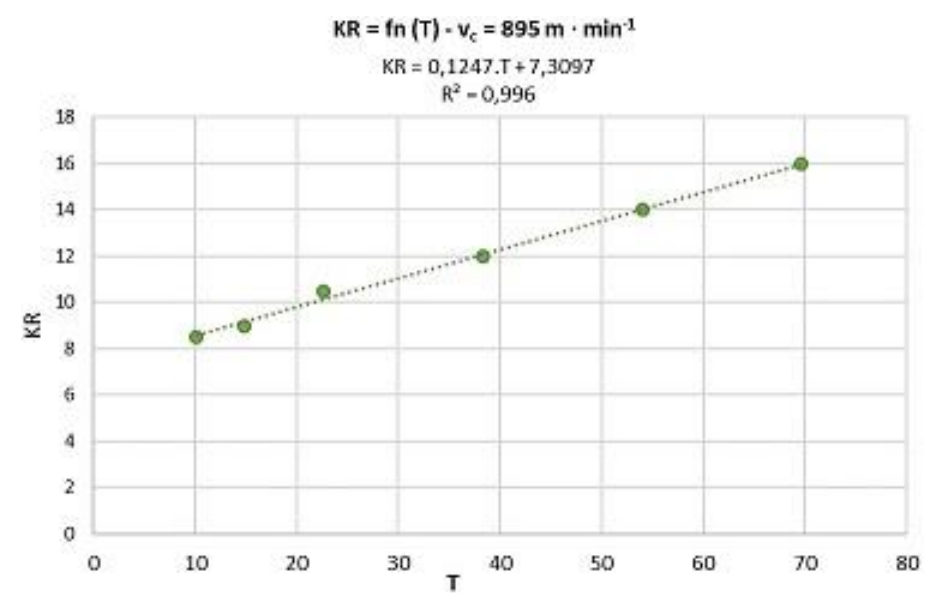

Fig. 9. The regression of linear wear for $v_{\mathrm{c} 3}=895 \mathrm{~m} / \mathrm{min}, \mathrm{KR}[\mu \mathrm{m}]$ and $T$ [min]

Table 5. Measurement of Tool Wear vs. Time, Inserts U3b / U4b, Speed $v_{c 4}=$ $1074 \mathrm{~m} / \mathrm{min}$

\begin{tabular}{|c|c|c|c|c|c|}
\hline $\begin{array}{c}\text { Measurement } \\
\text { No. }\end{array}$ & $\begin{array}{c}\text { Time } \\
(\mathrm{min})\end{array}$ & $\begin{array}{c}\text { Length of cut } \\
(\mathrm{mm})\end{array}$ & $\begin{array}{c}\text { Wear of U3b } \\
(\mu \mathrm{m})\end{array}$ & $\begin{array}{c}\text { Wear of U4b } \\
(\mu \mathrm{m})\end{array}$ & $\begin{array}{c}\text { Average } \\
\text { wear }(\mu \mathrm{m})\end{array}$ \\
\hline 1 & $\mathbf{0}$ & 0 & 0 & 0 & $\mathbf{0}$ \\
\hline 2 & $\mathbf{0 . 3 9}$ & 700 & 2 & 2 & $\mathbf{2 . 0}$ \\
\hline 3 & $\mathbf{0 . 7 8}$ & 700 & 3 & 3 & $\mathbf{3 . 0}$ \\
\hline 4 & $\mathbf{1 . 1 7}$ & 700 & 3 & 3 & $\mathbf{3 . 0}$ \\
\hline 5 & $\mathbf{1 . 5 6}$ & 700 & 5 & 4 & $\mathbf{4 . 5}$ \\
\hline 6 & $\mathbf{2 . 3 3}$ & 1400 & 6 & 5 & $\mathbf{5 . 5}$ \\
\hline 7 & $\mathbf{3 . 1 1}$ & 1400 & 8 & 8 & $\mathbf{8 . 0}$ \\
\hline 8 & $\mathbf{5 . 4 5}$ & 4200 & 9 & 9 & $\mathbf{9 . 0}$ \\
\hline 9 & $\mathbf{9 . 3 3}$ & 7000 & 10 & 9 & $\mathbf{9 . 5}$ \\
\hline 10 & $\mathbf{1 3 . 2 2}$ & 7000 & 11 & 11 & $\mathbf{1 1 . 0}$ \\
\hline 11 & $\mathbf{2 1 . 0 0}$ & 14000 & 12 & 12 & $\mathbf{1 2 . 0}$ \\
\hline 12 & $\mathbf{2 8 . 7 8}$ & 14000 & 14 & 13 & $\mathbf{1 3 . 5}$ \\
\hline 13 & $\mathbf{3 6 . 5 6}$ & 14000 & 15 & 15 & $\mathbf{1 5 . 0}$ \\
\hline
\end{tabular}

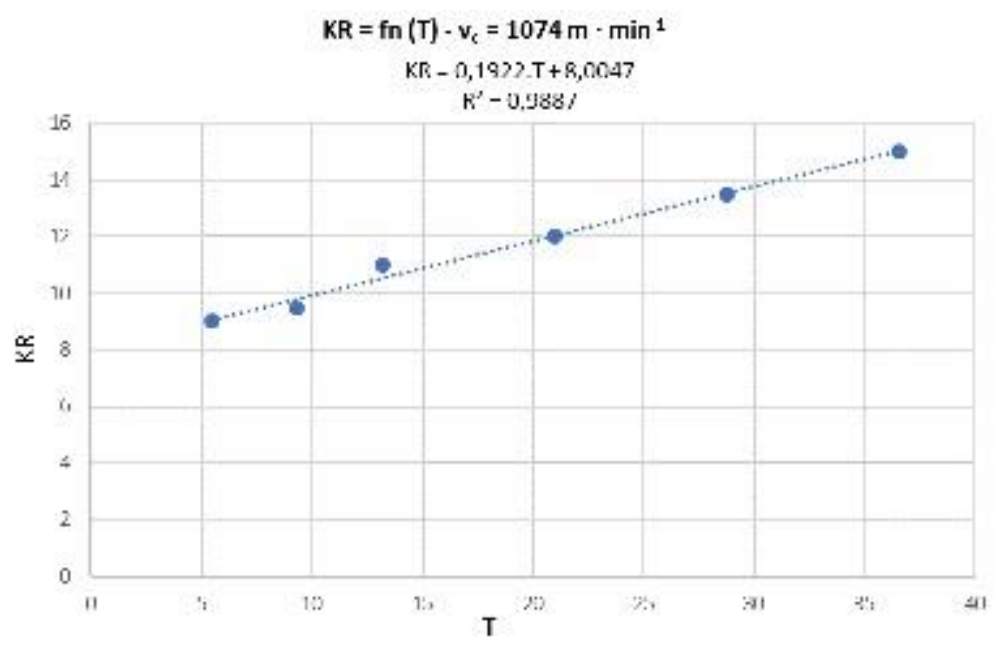

Fig. 10. The regression of linear wear for $v_{\mathrm{c} 4}=1074 \mathrm{~m} / \mathrm{min}, \mathrm{KR}[\mu \mathrm{m}]$ and $T[\mathrm{~min}]$

The relationship between tool life $T$ and cutting speed $v_{\mathbf{c}}$ is as follows: 


$$
T \cdot v_{c}^{m}=\text { const. }
$$

Here, the Taylor's equation replaces the exponent $m=1 / n$. A wear rate of $10 \mu \mathrm{m}$ from the original value of the cutting edge was determined as a criterion to state the tool life for that rate. To determine the dependence of tool life on cutting speeds, the $T$ and $v_{\mathrm{c}}$ values for the tool wear criterion were used into graphic representation $\log (T)=\mathrm{fn}\left(\log v_{\mathrm{c}}\right)$ (see Table 6). The statistical method of linear regression was then applied for solution. Confidence intervals $(95 \%)$ of the measured data $T=\mathrm{fn}\left(v_{\mathrm{c}}\right)$ graphs for laminate particle board materials were processed. Results are shown in Fig. 11.

Table 6. Cutting Speeds and Corresponding Tool Life T1-T4 for $K R=10 \mu \mathrm{m}$

\begin{tabular}{|c|c|c|c|}
\hline$v_{\mathrm{c} 1}=\mathbf{4 7 7} \mathrm{m} \cdot \mathrm{min}^{-1}$ & $v_{\mathrm{c} 2}=\mathbf{7 1 6} \mathrm{m} \cdot \mathrm{min}^{-1}$ & $v_{\mathrm{c} 3}=\mathbf{8 9 5} \mathrm{m} \cdot \mathrm{min}^{-1}$ & $v_{\mathrm{c} 4}=\mathbf{1 0 7 4} \mathrm{m} \cdot \mathrm{min}^{-1}$ \\
\hline $\mathrm{KR}=0,097 . T+3,9711$ & $\mathrm{KR}=0,0838 . T+7,4309$ & $\mathrm{KR}=0,1247 . T+7,3097$ & $\mathrm{KR}=0,1922 . T+8,0047$ \\
\hline$T_{1}=\mathbf{6 2 . 2} \mathrm{min}$ & $T_{2}=\mathbf{3 0 . 7} \mathrm{min}$ & $T_{3}=\mathbf{2 1 . 6} \mathrm{min}$ & $T_{4}=\mathbf{1 0 . 4} \mathrm{min}$ \\
\hline
\end{tabular}

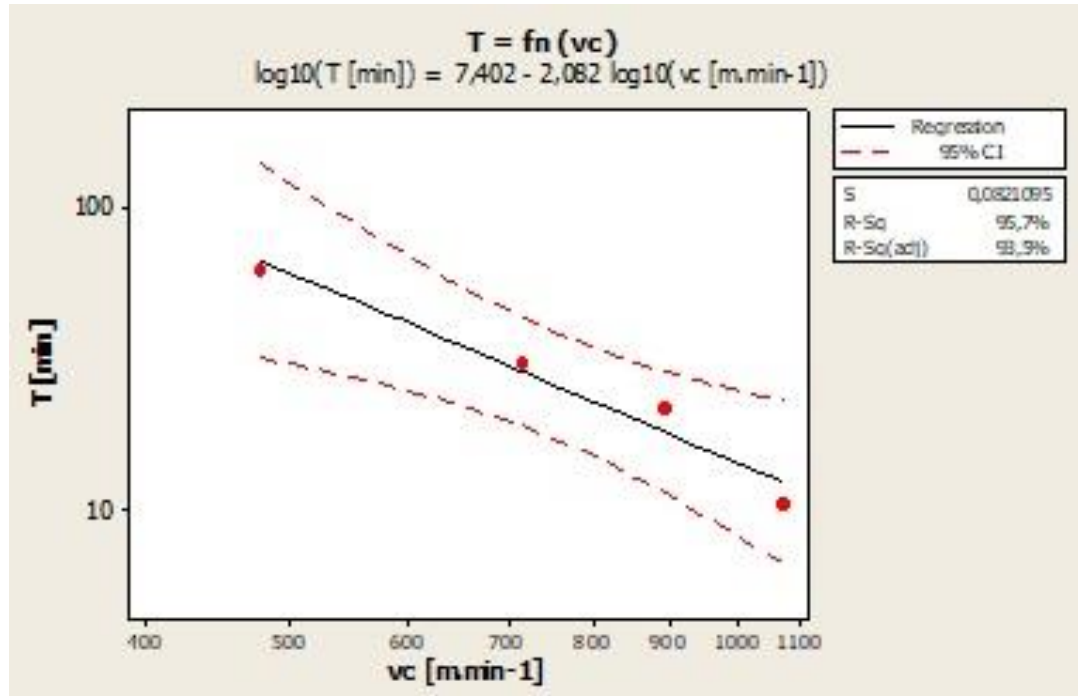

Fig. 11. Regression of $T=f n\left(v_{c}\right)$ with a confidence interval $95 \%$

Equation 5 corresponding to the function from the graphic representation in Fig. 11 is then in final formula (Eq. 6).

$$
T v_{\mathrm{c}}{ }^{2.082}=252.35 \times 10^{5} \text { or } \quad v_{\mathrm{c}} T^{0.48}=3590.7
$$

\section{CONCLUSIONS}

1. The wear mechanism of the particle board is different from the wear mechanism with abrasive particles that are characteristic of metals with abrasive particles. Darmawan at al. $(2001,2012)$ used the measurement of the wear on the clearance face. 
2. In the article, the comparative digital gauge used the measurement of radial wear KR that corresponds to cutting tool recession been used during the experiments. The course of the wear of wood-based materials exhibited similarity of the graphical representation with abrasive material cutting.

3. The final dependence $T=\mathrm{fn}\left(v_{\mathrm{c}}\right)$ for machining the laminated particle board to select the proper cutting rate for a given tool life was determined. The final equation may be used for calculation of cutting rate/tool life according to operator demands.

4. The criterion for determining tool life been selected in the linear part of wear curve to get proper and accurate results with the use of linear regression

5. The experiments were evaluated using regression analysis.

\section{ACKNOWLEDGEMENTS}

The authors greatly acknowledge the financial support provided by The Science Fund 2016, Brno University of Technology, Faculty of Mechanical Engineering FV 16-28 and the grant "Research of modern production technologies for specific applications," reg. no. FSI-S-16-3717 and the project VEGA 1/0642/18: "Analysis of impacts of constructional parts of forest mechanisms in forestry environment regarding to energetic and ecological demands."

\section{REFERENCES CITED}

Csanády, E., and Magoss, E. (2012). "Mechanics of Wood Machining" (2 ${ }^{\text {nd }}$ Ed.), Springer, New York, NY.

Darmawan, W., Tanaka C., Usuki H., and Ohtani T. (2001). "Performance of coated carbide tools in turning wood-based materials: Effect of cutting speeds and coating materials on the wear characteristics of coated carbide tools in turning wood-chip cement board," Wood Science 47(5), 342-349.

Darmawan, W., Rahayu, I., Nandika, D., and Marchal, R. (2012). "The importance of extractives and abrasives in wood materials on the wearing of wood cutting tools," BioResources 7(4), 4715-4729. DOI: 10.15376/biores.11.4.4715-4729

Gaff, M., Sarvašová-Kvietková, M., Gašparík, M., and Slávik, M. (2016). "Dependence of roughness change and crack formation on parameters of wood surface embossing" Wood Research 61(1), 163-174.

Kučerová, V., Lagaňa, R., Výbohová, E., and Hýrošová, T. (2016). "The effect of chemical changes during heat treatment on the color and mechanical properties of fir wood," BioResources 11(4), 9079-9094. DOI: 10.15376/biores.11.4. 9079-9094

Kvietková, M., Gaff, M., and Gašparík, M. (2015a). "Effect of thermal treatment on surface quality of beech wood after plane milling," BioResources 10(3), 4226-4238. DOI: 10.15376/biores.10.3. 4226-4238

Kvietková, M., Gaff, M., Gašparík, M., Kaplan, L., and Barcík, Š. (2015b). “Surface quality of milled birch wood after thermal treatment at various temperatures," BioResources 10(4), 6512-6521. DOI: 10.15376/biores.10.4. 6512-6521

Kvietková, M., Gaff, M., Gašparík, M., Kminiak, R., and Kris, A. (2015c). "Effect of 
number of saw blade teeth on noise level and wear of blade edges during cutting of wood," BioResources 10(1), 1657-1666. DOI: 10.15376/biores.10.1.1657-1666

Mazáň, A., Vančo, M., and Barcík, S. (2017). "Influence of technological parameters on tool durability during machining of juvenile wood," BioResources 12(2), 2367-2378. DOI: 10.15376/biores.12.2. 2367-2378

Šebelová, E. and Chladil, J. (2013). "Tool wear and machinability of wood-based materials during machining process," Manufacturing Technology 13(2), 231-236.

Sedlecký, M., and Sarvašová Kvietková, M. (2017). "Surface waviness of mediumdensity fibreboard (MDF) and edge-glued panel EGP after edge milling," Wood Research 62(3), 459-470.

Shaw, M. C. (2005). "Metal Cutting Principles" (2 ${ }^{\text {nd }}$ Ed.), Oxford University Press, Oxford, UK.

Thoemen, H., Irle, M., and Sernek, M. (2010). Wood-based Panels - An Introduction for Specialists, Brunel University Press, London.

Submitted: December 12, 2018; Peer review completed: February 17, 2019; Revised version received and accepted; March 5, 2019; Published: March 8, 2019.

DOI: 10.15376/biores.14.2.3495-3505 